\title{
Affective Variables from the Applied Linguistics Perspective: A Study of the Saudi Undergraduate Students Majoring in English Language
}

\author{
Dr. Khaled Elkotb Mahmoud Elshahawy \\ Assistant Professor of Applied Linguistics-English Language Teaching \\ Al-Baha University, English Language Center, Saudi Arabia \\ Tel: 966-538-422-918Ｅ-mail: elshahawy.smsm@yahoo.com
}

Received: January 5, 2020 Accepted: January 27, 2020 Published: January 29, 2020

doi:10.5296/jsel.v8i1.16357 URL: https://doi.org/10.5296/jsel.v8i1.16357

\begin{abstract}
The present study aimed at indicating the effect of the affective variables (motivation, attitude, self-confidence and willingness to communicate) on the acquisition and learning of English language among the students of Languages and Translation Departments in the Kingdom of Saudi Arabia. The study participants were 40 students (20 males and 20 females) from the students specialized in English language. The study used three instruments: The semi-structured interview, affective variables questionnaire (AVQ) and English language proficiency observation checklist (ELPOC). The study adopted the quasi-experimental design mixed with the qualitative interpretation. The study employed the correlational analysis and the simple liner regression to indicate the relationship between the independent and dependant variables. The findings of the study showed that there is a positive significant relationship between the affective variables (motivation, attitude, self-confidence and willingness to communicate) and the process of English language acquisition as a second language. The study also demonstrated that the most influential factors in the learners' English language acquisition process is their willingness to communicate. Recommendations and suggestions based on the study results were directed to the L2 (EFL/ESL) instructors and all the specialists in English language acquisition and learning.
\end{abstract}

Keywords: Affective Variables; Applied Linguistics; English Language Acquisition; L2 (ESL/EFL); Correlation; Proficiency 


\section{Introduction}

A prime rationale of second language (L2) investigation is to decide what variables obstruct or help L2 (EFL/ESL) acquisition. Among these variables are the affective variables. According to Gass and Selinker (2008: 398), affective variables are the "feelings or emotional reactions about the language, about the people who speak the language, or about the culture where that language is spoken". According to Arnold (2009), the term affect is the area of beliefs, feelings, emotions, attitudes and moods which have an impact on the students' linguistic or language conduct. Therefore, the affective variables are paramount to consider on learning or teaching English as a second or foreign language. According to the researchers and theorists in Applied linguistics, second language acquisition (SLA) (e.g. Marcos-Llinàs, 2007; Muñoz and Martín, 2015), the affective variables incorporate motivation, self-confidence, self -esteem, willingness to language acquisition or learning, attitude, autonomy and anxiety. In the current study, the focus is on the affective variables that include motivation, attitude, self-confidence and willingness to communicate and their relation to the English language acquisition of the Saudi students of Languages and Translation Departments majoring in English language.

\subsection{Motivation}

Generally speaking, among the affective variables that play a considerable function in the process of acquiring or learning L2 (ESL /EFL) language is motivation. This is obvious in Dornyei and Otto's (1998) claim that motivation is the driving force that pushes learning L2 and has impacts on both the rate and success of the process of learning and acquisition. In the same vein, motivation is strongly related to the other affective variables. For example, Clement, et al.,( 1994) found that students with lower motivation have lower self-confidence in acquiring or learning L2, on the contrary with those who have higher motivation, tend to have higher self-confidence in acquiring or learning L2. Regarding the magnitude of motivation in the L2(ESL/EFL) learning and acquisition, the literature made it clear as stated by several researchers (e.g. Ortega, 2009; Saville-Troike, 2012) that motivation is the learner's compelling force in learning or acquiring his/her L2 (EFL/ESL).

\subsection{Attitudes towards L2 (ESL/EFL)}

In this study, L2 (ESL/EFL) attitudes as indicated by SLA researchers (e.g. Gardner, 2001; Knell and Chi, 2012) include the target language attitudes, the attitudes toward people who speak that target language, the attitudes towards the L2 culture, L2 teachers and L2 course or curriculum. The significance of L2 (ESL/EFL) attitudes in acquiring or learning English language appears in its interchangeable relation with L2 motivation. In other terms, if L2 learners have positive attitudes towards English language, they will be highly motivated to learn and acquire it. As indicated by Dörnyei's Motivational Self System theory which demonstrated the vital relationship between attitudes and motivation (Dörnyei and Ushioda, 2009).This relation is a clear evidence as illustrated by L2 researchers (e.g. Alrabai, 2014; Gardner, 2010) that the positive attitudes of the target language learners towards the language, its speakers and its culture lead to highly-motivated L2 learners and thus, higher L2 achievement or performance. 


\subsection{Willingness to Communicate}

Willingness to Communicate (WTC) is an affective variable very significant for English language learners' acquisition or learning process.WTC was originally adapted for an L2 (ESL/EFL) context by McIntyre (1994) who created a path model proposing that WTC has two key components: communication apprehension and perceived communication competence. In this context, WTC can be defined as stated by several researchers like Donovan and McIntyre (2004) as a notion that concentrates on how language learners will make use of any opportunities to communicate in a second, or foreign, language. This demonstrates its relation to the other affective variables such as language anxiety. As stated by Samimy and Tabuse (1992) that language anxiety has a straight impact on "willingness to communicate", thus, it might lead to the L2 (ESL/EFL) learners' lack of confidence in their abilities to communicate in the target language. This highlights the affective variable of self-confidence in acquiring and learning L2 (ESL/EFL).

\subsection{Self-Confidence}

Self- confidence is a very important affective variable that can affect the L2 (ESL/EFL) learners' communicative competence as stated by Clement, et al. (1994). According to MacIntyre, et.al (2003) self-confidence in L2 (ESL/EFL) can be identified as the overall belief in being able to communicate in the $\mathrm{L} 2$ in an adaptive and productive manner. The significance of L2 learners' self-confidence appears in its influence on the learners' linguistic competence. Pertaining to its impact on the L2 (ESL/EFL) linguistic competency, Clement, et al. (1994) declare that, if L2 learners have high self- confidence, they will highly motivated to get involved in practicing the L2, thus, their linguistic competency will be increased. For the purpose of this study, highlighting some of the literature that has been conducted on the influences of affective variables in acquiring or learning English as L2 (ESL/EFL) is beneficial in this concern.

The interconnectedness between the L2 (EFL/ESL) learners' acquisition and the affective variables (motivation, attitude, willingness to communicate, self-confidence) appeared clearly in several related studies. Among these studies are the studies of Basco and Ho Han (2016); Chen (2009) ; Dehbozorgi (2012); Ebrahimi and Heidarypur (2016); Farouk (2016); Khaleghi (2016); Knell and Chi (2012); Muñoz and Martín (2015); Nafi, et al. (2016); Ranjbar and Narafshan (2016); Törnqvist (2008); Zaman (2015); Zhu and Zhou (2012). These studies investigated the affective variables and its impact on L2 (ESL/EFL) learning or acquisition from different perspectives.

Some of them focused on motivation and attitudes towards learning English and oral communication (e.g. Dehbozorgi, 2012; Ebrahimi and Heidarypur, 2016; Nafi, et al., 2016; Zaman, 2015; Törnqvist, 2008). Other studies concentrated on the variables of motivation, attitudes, willingness to communicate and language anxiety (e.g. Farouk, 2016; Knell and Chi, 2012). Furthermore, some studies highlighted lack of self- confidence and language anxiety on the learners' effective participation in the oral communication (e.g. Basco and Ho Han , 2016; Khaleghi, 2016 ). 


\section{MInstitute ${ }_{\text {Intm }}^{\text {Macrothink }}$}

Moreover, some studies demonstrated the connection among anxiety, attitude and motivation and their effect on the academic performance of the L2 (ESL/EFL) learners (e.g. Muñoz and Martín 2015). In addition, one study (Ranjabar and Narafshan, 2016) investigated the relationship between teachers' affective factors (motivation, anxiety, attitude, and self-confidence) and students' motivation in EFL classrooms. Finally, these studies investigated the impact of the affective variables named in the current study in different educational contexts including the university level and the pre-university level.

On the Saudi context, there are few studies (e.g. Alkaabi, 2016; Alrabai and Moskovsky, 2016; Moskovsky and Alrabai, 2009; Sadiq, 2017) that highlighted the relationship between the affective variables as mentioned in this study and the acquisition or learning 12 (EFL/ESL). Elaborating on some of them will be useful in this concern. For example, Alrabai and Moskovsky (2016) conducted their study with the aim of investigating the influence of five affective variables, namely, motivation, attitudes, anxiety, self-esteem and autonomy, together or individually on L2 (ESL/EFL) learners' achievement. The study participants were Saudi University students learning English as L2 (ESL/EFL) as part of their university degree. The study used the instruments of a questionnaire and a language test. The descriptive and inferential analyses of the study data demonstrated the significance of the affective variables in relation to L2 (ESL/EFL) learning and acquisition.

After this short review of the literature that has been conducted in this language area, several benefits emerge for the current research. Firstly, it helps in designing and determining the instruments, methods of analyzing the collected data and procedures of the current study. Secondly, it is obvious from this short review on the studies that have been conducted on the relationship of the affective variables and the L2 (ESL/EFL) learning or acquisition, that there is a correlation between them. Thirdly, numerous studies clarified and proved this relation in several L2 (ESL/EFL) contexts, in the Saudi context there are very few studies that have been investigated and exposed this correlation between the L2 learning, acquisition or achievement and the affective variables. All these reasons were motives for the researcher to conduct the current study.

\section{Statement of the Problem}

Learning English in Saudi Arabia, particularly, on the university level still constitutes a corner stone in front of several Saudi university students. Among the problems that encounter students is their weak affective variables (motivation, attitude, willingness to communicate, self-confidence) towards learning or acquiring English language.

\section{Purpose of the Study}

The current study aimed at examining the correlation of the language affective variables of motivation, attitude, willingness to communicate, self-confidence and the acquisition and learning of the English language for the students of Languages and Translation Departments majoring in English language in Saudi Arabia. 


\section{Questions of the Study}

Based on the problem and purpose of the present study, the following main research question was formulated: What is the relationship of the language affective variables with the English language acquisition of the EFL students of Languages and Translation Departments in Saudi Arabia? In order to answer it, it was divided into the following sub-questions:

1-What is the relationship of language motivation with the English language acquisition of the EFL Saudi students of Languages and Translation Departments?

2-What is the relationship of language attitude with the English language acquisition of the EFL Saudi students of Languages and Translation Departments?

3-What is the relationship of English language learners' willingness to communicate with the English language acquisition of the EFL Saudi students of Languages and Translation Departments?

4-What is the relationship of the English language learners' self- confidence with the English language acquisition of the EFL Saudi students of Languages and Translation Departments?

\section{Hypotheses of the Study}

To address these five quantitative research questions, the study tested five research hypotheses concerning the correlation of the affective variables with the English language acquisition the EFL Saudi students of Languages and Translation Departments:

H1-There is a statistically significant positive relationship between the affective variables and English language acquisition in the application of questionnaire and observation checklist statements on the experimental group students.

H2-There is a statistically significant positive relationship between language motivation and English language acquisition in the application of the questionnaire and observation checklist statements on the experimental group students.

H3-There is a statistically significant positive relationship between language attitude and English language acquisition in the application of the questionnaire and observation checklist statements on the experimental group students.

H4-There is a statistically significant relationship between the learners' self-confidence and English language acquisition in the application of the questionnaire and observation checklist statements on the experimental group students.

H5-There is a statistically significant relationship between the learners' willingness to communicate and English language acquisition in the application of the questionnaire and observation checklist statements on the experimental group students.

\section{Significance of the Study}

The current study is important for all the researchers, educationalist and tutors working in the field of English language acquisition or learning. As it provides them with insights and 
visions on how the affective variables generally, especially, language motivation, language attitude, learners' willingness to communicate and learners' self-confidence affect on the process of English language acquisition or learning. Definitely, this will improve the process of English instruction on the part of the instructors, as they will work on increasing the positive affective variables and decrease or reduce the effects of the negative ones.

\section{Delimitations of the Study}

The delimitations of the current study were identified in the following:

1. The participants of the study included the students from the Department of Languages and Translation, Taymaa Campus, University of Tabuk, male and female students, aged 18 to 23 .

2. The study was conducted concentrating on the affective variables of motivation, attitude and self-confidence willingness to communicate.

3. The study demonstrated the correlation of these affective variables with the acquisition of English language.

\section{Methodology of the Study}

\subsection{Participants of the Study}

Forty male and female students from University College of Taymaa, Department of Languages and Translation, University of Tabuk, Saudi Arabia, in the academic year $2018 / 2019$, second semester, were selected based on convenience or opportunity sampling to be the participants of the study. This interprets the small number of the study participants.

\subsection{Participants Demographic Variables}

The participants' demographic information are displayed with respect to their age, sex, academic level of education (Year in the specific undergraduate program) as indicated in table (1).

Table (1). Participants' Demographic Information

\begin{tabular}{|c|c|c|c|c|c|}
\hline $\begin{array}{c}\text { Academic } \\
\text { undergraduate level of } \\
\text { education }\end{array}$ & Sex & Age & Frequency & Percent & $\begin{array}{c}\text { Valid } \\
\text { percent }\end{array}$ \\
\hline \multirow{2}{*}{ First } & Male & $18-19$ & 5 & $12.5 \%$ & $12.5 \%$ \\
\cline { 2 - 6 } & Female & $18-19$ & 5 & $12.5 \%$ & $12.5 \%$ \\
\hline \multirow{2}{*}{ Third } & Male & $19-20$ & 5 & $12.5 \%$ & $12.5 \%$ \\
\cline { 2 - 6 } & Female & $19-20$ & 5 & $12.5 \%$ & $12.5 \%$ \\
\hline \multirow{2}{*}{ Fifth } & Male & $20-21$ & 5 & $12.5 \%$ & $12.5 \%$ \\
\cline { 2 - 6 } & Female & $20-21$ & 5 & $12.5 \%$ & $12.5 \%$ \\
\hline & Male & $21-22$ & 5 & $12.5 \%$ & $12.5 \%$ \\
\hline
\end{tabular}




\begin{tabular}{|c|c|c|c|c|c|}
\hline \multirow{2}{*}{ Seventh } & & & & & \\
\cline { 2 - 6 } & Female & $21-22$ & 5 & $12.5 \%$ & $12.5 \%$ \\
\hline Total & & & 40 & $100 \%$ & $100 \%$ \\
\hline
\end{tabular}

\subsection{Study Design}

The present study adopted the quasi-experimental design, as there was no control group. One experimental group of 40 students ( 20 males and 20 females) was formed this because the participants were selected based on convenience or opportunity sampling to be the participants of the study. In addition, the study adopted a corelational design, with two main variables: 1) independent variables included the affective variables of motivation, attitude, willingness to communicate and self- confidence; and 2) dependent variables of English language acquisition. Moreover, it included a qualitative interpretation to calculate the results and elaborate on them. Figure (1) demonstrates the study design.

Pre-Application $\quad$ One Group $\quad$ Treatment $\quad$ Post-Application

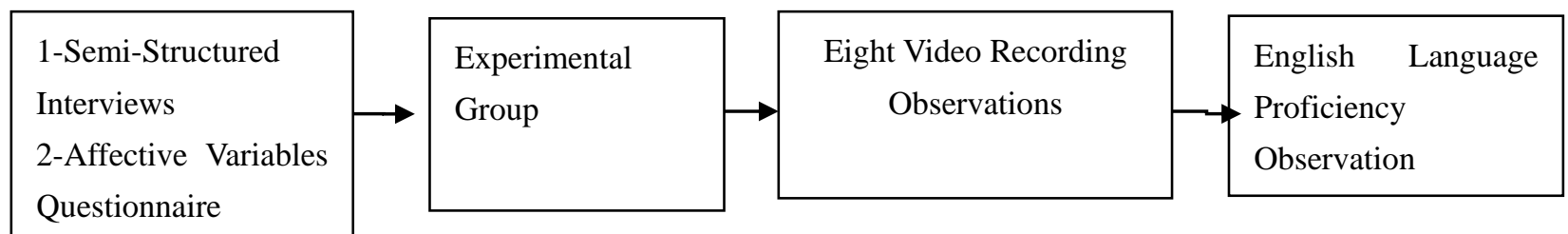

Figure (1): The Quasi-Experimental Design of the Study

\subsection{Instruments of the Study}

The current study employed three instruments. They were designed by the researcher and validated by the jurors to be used in the current research:

\subsubsection{Semi-structured (systematic) Interview}

Ten students ( 5 males and 5 females) rather than the participants of the study were videotaped interviewed. The type of these interviews were semi-structured interviews. It included seven questions related to the impact of the affective variables, particularly, motivation, attitude, willingness to communicate and self-confidence on acquiring English language. Some resources and related research were elaborated on to construct the questions of this interview (e.g. Altmisdort, 2016; Muñoz, 2014). The researcher interviewed the male students while one female colleague from the female campus interviewed the female students. The collected data was used to help in designing the statements of the affective variables questionnaire and the English language proficiency observation checklist.

\subsubsection{Affective Variables Questionnaire (AVQ)}

In the current study, affective variables questionnaire was used to collect the data demonstrating the correlation between the participants' affective variables and their acquisition of the English language (See Appendix 1). The statements of the AVQ were built 
and designed upon the collected data from the tenth students' interviews. In addition to some other resources were drawn upon them (e.g. Alkaabi, 2016; Ebrahimi \& Heidarypur, 2016; El-Shahawy, 2017; Nafi, et al., 2016; Sadiq, 2017).The AVQ included 24 statements designed to collect data related to the four affective variables (i.e. motivation, attitude, willingness to communicate and self-confidence) of the current study and their correlation with the participants' English language acquisition. Every six statements were related to one affective variable.

The administration of the questionnaire occurred in both the male and female campuses with the help of the researcher's colleagues on January 13, 14/ 2019. The AVQ was from the type of the four-point Likert scale ranging from Strongly Disagree to Strongly Agree. During administration of the AVQ, the participants were told of its purpose and how it was used for just collecting data for the current study. They were also informed that there were no wrong or right answers and they should feel free to tick any option honestly and frankly according to their own opinion and language experience.

\subsubsection{English Language Proficiency Observation Checklist (ELPOC)}

English Language Proficiency Observation Checklist (ELPOC) was developed by the researcher based on the data collected from the interviews (See Appendix 2) to observe the study participants' English language proficiency and performance within their English classroom lectures. Some resources were used also (e.g. Ibrahim \& Ibrahim, 2017; Rasch, 2016). The ELPOC included statements related to language areas e.g. macro skills (speaking, listening, reading and writing), vocabulary and grammatical structures. As the correlation between these statements and those of the AVQ would be investigated and analyzed statistically. The levels of performance on the ELPOC evaluation scale were ranging from: Below standards (1), Approaching standards (2), Meeting standards (3) and Above standards (4). The observation sessions (8 sessions, two sessions for each academic undergraduate level (i.e.4 levels), one for male campus and another for the female campus) were videotaped in order to allow the researcher to observe what was missed during the lecture and to give more validity and clarity for the observation sessions as well.

\subsection{Validity and Reliability}

The three study instruments were validated by (8) English language professors:(4) Associate Professors specialized in applied linguistics-ELT; (2) Assistant Professors specialized in theoretical linguistics and (2) Assistant Professors specialized in translation at the University of Tabuk in Saudi Arabia and Mansoura University in Egypt. Their recommendations and suggestions were considered. As for the reliability of the instruments, the internal consistency of the coefficient reliability of the questionnaire and the observation checklist were found to be (.764) and (.720) respectively.

\subsection{Pilot Study}

The interview was piloted on two students and the affective variables questionnaire (AVQ) and English Language Proficiency Observation Checklist (ELPOC) were piloted on ten students rather than the participants of the study from each campus, namely, the male and 
female campuses, in order to:

1-Check the appropriate time allocated for each instrument;

2-Make sure the words and phrases of the interview and AVQ were clear for the participants;

4-Make sure of the internal consistency of the coefficient reliability of the questionnaire and the observation checklist which was found to be (.764) and (.720) respectively.

3- Be aware of the procedures that would be followed when using each instrument.

\subsection{The Procedures of the Study}

The literature and the previous studies related to the affective variables of motivation, attitude, willingness to communicate, self-confidence, and their impact on the process of English language acquisition were reviewed. After reviewing the related literature and based on the researchers' work experience (Assistant professor of applied linguistics, ELT) at the University of Tabuk for two years, the interview instrument was designed and developed. Based on the data collected from the students' interview and the related literature the affective variables questionnaire (AFQ) was drawn and built upon by the researcher. After that the English Language Proficiency Observation Checklist (ELPOC) was created as well. Its statements were built based on the process of the English language acquisition, namely, macro skills (listening, speaking, reading, writing, vocabulary and grammatical competence...etc.).

The study instruments were validated by 8 English language professors: 4 Associate Professors specialized in applied linguistics, TEFL; 2 Assistant Professors specialized in theoretical linguistics and 2 Assistant Professors specialized in translation, as their suggestions and feedback were worked on them. Cronbach Alpha coefficient for internal consistency using the SPSS program was used to achieve the reliability of the instruments. Affective variables questionnaire reliability (AFQ) was (.764) and that of the English Language Proficiency Observation Checklist (ELPOC) was (.720). After conducting the interview and building upon the AFQ, it was administered to the experimental group in the first week of the second term of the academic year 2018/2019 to recognize the participants' (males and females) views concerning the affective variables and their effect on their acquisition of the English language. The English Language Proficiency Observation Checklist was a administered and videotaped eight times, four for males and four for females, in the first and second months of the second term of the academic year 2018/2019 to allow the researcher to observe all participants and all language areas that were needed to observed. The observation sessions that happened at the female campus were done with the help of one of the female colleagues. The data from the AFQ and ELPOC were collected and analyzed quantitatively and qualitatively.

\section{Study Results}

SPSS statistics program (Ver.19) was used to analyze the data after the data collection and estimating the variables scores. In this mixed approach study, correlation coefficients and multiple regression analysis were used to analyze the collected data. The variables of the 
study included four affective variables (motivation, attitude, self-confidence and willingness to communicate) and the English language acquisition variable. According to the analysis of the data, each participants was given two main scores related to the two main variables of the study. The first was for the affective variables questionnaires, which was given values from 1 to 4 and its total score. The total score of the questionnaire which is (96) is distributed among the four affective variables of motivation, attitude, self-confidence and willingness to communicate as each affective variable of them was given values from 1 to 4 and a total score for each of them (i.e. Motivation (24), attitude (24), self-confidence (24) and willingness to communicate(24)). The second main score is related to the English language acquisition, which is represented by the English Language Proficiency Observation Checklist. This observation checklist was given values from 1 to 4 and its total score is (96).

Before answering the study questions and verifying the hypotheses, it is worth using inferential statistical analyses to examine the relationships among the four affective variables of the current study. The results are demonstrated in table (2):

Table (2): Correlations Among the Affective Variables

\begin{tabular}{|c|c|c|c|c|c|}
\hline \multicolumn{2}{|c|}{ Affective Variables Correlation } & \multirow{2}{*}{$\begin{array}{l}\text { Motivation } \\
\text { Variable }\end{array}$} & \multirow{2}{*}{$\begin{array}{l}\begin{array}{l}\text { Attitude } \\
\text { Variable }\end{array} \\
.981^{* *}\end{array}$} & \multirow{2}{*}{$\begin{array}{c}\text { Self } \\
\text {-Confidence } \\
\text { Variable } \\
.949^{* *}\end{array}$} & \multirow{2}{*}{$\begin{array}{l}\text { Willingness to } \\
\text { Communicate } \\
\text { Variable } \\
.953^{* *}\end{array}$} \\
\hline Motivation Variable & $\begin{array}{l}\text { Pearson } \\
\text { Correlation }\end{array}$ & & & & \\
\hline & Sig. (2-tailed) & & .000 & .000 & .000 \\
\hline & $\mathrm{N}$ & 40 & 40 & 40 & 40 \\
\hline \multirow[t]{3}{*}{ Attitude Variable } & $\begin{array}{l}\text { Pearson } \\
\text { Correlation }\end{array}$ & $.981^{* *}$ & 1 & $.963^{* *}$ & $.970^{* *}$ \\
\hline & Sig. (2-tailed) & .000 & & .000 & .000 \\
\hline & $\mathrm{N}$ & 40 & 40 & 40 & 40 \\
\hline \multirow[t]{3}{*}{$\begin{array}{l}\text { Self-Confidence } \\
\text { Variable }\end{array}$} & $\begin{array}{l}\text { Pearson } \\
\text { Correlation }\end{array}$ & $.949^{* *}$ & $.963^{* *}$ & 1 & $.961^{\text {** }}$ \\
\hline & Sig. (2-tailed) & .000 & .000 & & .000 \\
\hline & $\mathrm{N}$ & 40 & 40 & 40 & 40 \\
\hline \multirow{3}{*}{$\begin{array}{l}\text { Willingness to } \\
\text { Communicate } \\
\text { Variable }\end{array}$} & $\begin{array}{l}\text { Pearson } \\
\text { Correlation }\end{array}$ & $.953^{* *}$ & $.970^{* *}$ & $.961^{* *}$ & 1 \\
\hline & Sig. (2-tailed) & .000 & .000 & .000 & \\
\hline & $\mathrm{N}$ & 40 & 40 & 40 & 40 \\
\hline
\end{tabular}

**. Correlation is significant at the 0.01 level (2-tailed) Or $* * p<0.01,{ }^{*} p<0.05$. 


\section{MInstitute ${ }^{\text {Mink }}$}

Table (2) indicates that there is a statistically significant correlation (at the 0.01 and 0.05 level) among the affective variables of the study. As r (40) = (.981), (.949), (.953), (.963), (.961), (.953), (.970), $\mathrm{p}=(.000)$. These values mean that there is a positive relation between all the four affective variables of motivation, attitude, self-confidence and willingness to communicate respectively. In order to answer the study questions and verify its hypotheses, the correlational relationships between each of those variables and the language acquisitions variable represented by the observation checklist statements are going to be estimated.

\section{To Answer the First Study Question and Test the Second Hypothesis}

This is going to be measured through indicating the correlational relationship between the motivation variable statements and the English Language Proficiency Observation Checklist (ELPOC) statements as indicated in table (3).

Table (3): Correlations Between Motivation and Observation Checklist Statements

\begin{tabular}{|c|l|r|r|}
\hline \multicolumn{2}{|c|}{$\begin{array}{c}\text { Motivation and Observation Checklist } \\
\text { Correlations }\end{array}$} & $\begin{array}{c}\text { Motivation Variable } \\
\text { Statements }\end{array}$ & $\begin{array}{c}\text { Observation Checklist } \\
\text { statements }\end{array}$ \\
\hline \multirow{2}{*}{$\begin{array}{c}\text { Motivation Variable } \\
\text { Statements }\end{array}$} & $\begin{array}{l}\text { Pearson } \\
\text { Correlation }\end{array}$ & 1 & $.698^{* *}$ \\
\cline { 2 - 4 } & Sig. (2-tailed) & 40 & .000 \\
\cline { 2 - 5 } & $\mathrm{N}$ & $.698^{* *}$ & 40 \\
\hline $\begin{array}{c}\text { Observation Checklist } \\
\text { statements }\end{array}$ & $\begin{array}{l}\text { Pearson } \\
\text { Correlation }\end{array}$ & .000 & 40 \\
\cline { 2 - 5 } & Sig. (2-tailed) & 40 & \\
\cline { 2 - 5 } & $\mathrm{N}$ & & \\
\end{tabular}

**. Correlation is significant at the 0.01 level (2-tailed).

As it is obvious in table (3), there is a statistically significant correlations (at the 0.01) between the motivation statements and the English Language Proficiency Observation Checklist (ELPOC). This relationship is positive because $r(40)=(.698), p=(.000)$. In other terms, the students who are highly motivated to learn and acquire English language, they have highly English language proficiency and this appeared during their observation using the ELPOC. This is also appears in the simple liner regression between the independent variable of motivation (motivation statements in AVQ) and the dependent variable of English language acquisition (statements of ELPOC) as shown in table (4).

Table (4): Simple Regression Coefficients for Language Motivation Variable Statements as Predictor of Observation Checklist statement

\begin{tabular}{|c|c|c|c|c|c|}
\hline \multirow{2}{*}{$\begin{array}{l}\text { Language Motivation Variable } \\
\text { and Observation Checklist } \\
\text { Regression }\end{array}$} & \multicolumn{2}{|c|}{ Unstandardized Coefficients } & $\begin{array}{l}\text { Standardized } \\
\text { Coefficients }\end{array}$ & \multirow[b]{2}{*}{$\mathrm{T}$} & \multirow[b]{2}{*}{ Sig. } \\
\hline & $\mathrm{B}$ & Std. Error & Beta & & \\
\hline (Constant) & 6.810 & 2.237 & & 3.044 & .004 \\
\hline
\end{tabular}




\begin{tabular}{|r|r|r|r|r|r|r|}
\hline \multicolumn{2}{|c|}{$\begin{array}{c}\text { Motivation Variable } \\
\text { Statements }\end{array}$} & .646 & .107 & .698 & 6.008 & .000 \\
\hline $\mathrm{R}$ & R Square & $\begin{array}{c}\text { Adjusted R } \\
\text { Square }\end{array}$ & \multicolumn{4}{|c|}{ Std. Error of the Estimate } \\
\hline $.698^{\mathrm{a}}$ & .487 & .474 & \multicolumn{5}{|c|}{1.514} \\
\hline
\end{tabular}

a. Predictors: (Constant), Motivation Variable Statements

b. Dependent Variable: Observation Checklist statements

As Table (4) indicates, the regression coefficient demonstrates the prediction equations. The R2of (0.487) indicates that, on the whole, about (48.7\%) of the variation in the dependent variables could be accounted for by the independent variable of the study. The coefficients labeled "Beta" is the standardized coefficient. These coefficients indicate the direction and strength of the relationship between the predictor variable (Language motivation) and the dependent variable (English language acquisition) is to estimate the strength of the effect of the independent variable on the dependent variable. The independent variable with the largest standardized Beta has the strongest effect. The results of the regression analysis revealed that the motivation variable predicts the students' English language acquisition with a beta weight of (.698) which is a positive value. All this answers the first study question, verifies, and accepts its second hypothesis $(\mathrm{p}=.000)$ which is: There is a statistically significant positive relationship between language motivation and English language acquisition in the application of the questionnaire and observation checklist statements on the experimental group students.

\section{To Answer the Second Study Question and Test the Third Hypothesis}

Identifying the correlational relationship between the participants' language attitude as indicated in the Affective variable questionnaire (AVQ) and their English Language Proficiency as represented in the Observation Checklist (ELPOC) answers the second question as indicated in table (5):

Table (5): Correlations between Attitude Variable Statements and ELPOC

\begin{tabular}{|c|c|c|c|}
\hline \multicolumn{2}{|c|}{$\begin{array}{c}\text { Attitude and Observation Checklist } \\
\text { Correlations }\end{array}$} & Attitude Variable & $\begin{array}{c}\text { Observation } \\
\text { Checklist statements }\end{array}$ \\
\hline \multirow[t]{3}{*}{ Attitude Variable } & $\begin{array}{l}\text { Pearson } \\
\text { Correlation }\end{array}$ & 1 & $.750^{* * *}$ \\
\hline & Sig. (2-tailed) & & .000 \\
\hline & $\mathrm{N}$ & 40 & 40 \\
\hline \multirow[t]{3}{*}{$\begin{array}{l}\text { Observation Checklist } \\
\text { statements }\end{array}$} & $\begin{array}{l}\text { Pearson } \\
\text { Correlation } \\
\end{array}$ & $.750^{* * *}$ & 1 \\
\hline & Sig. (2-tailed) & .000 & \\
\hline & $\mathrm{N}$ & 40 & 40 \\
\hline
\end{tabular}

**. Correlation is significant at the 0.01 level (2-tailed).

Table (5) denotes that there a statistically significant relationship between the two variables of the participants' language attitude and their English language acquisition represent in their 
performance in the English Language Proficiency Observation Checklist (ELPOC). This relationship is positive and statistically significant as the correlation between the two variables is $\mathrm{r}(40)=(.750), \mathrm{p}=(.000)$. This relation also gives acceptance for the second research hypothesis as $\mathrm{p}=(.000)$ which is less than (0.01). In other terms, the higher the participants' language attitude is, the higher of their English language acquisition is. This can also demonstrated in conducting a simple liner regression between these two variables as indicated in table (6).

Table (6): Simple Regression Coefficients for Language Attitude Variable Statements as Predictor of Observation Checklist statements

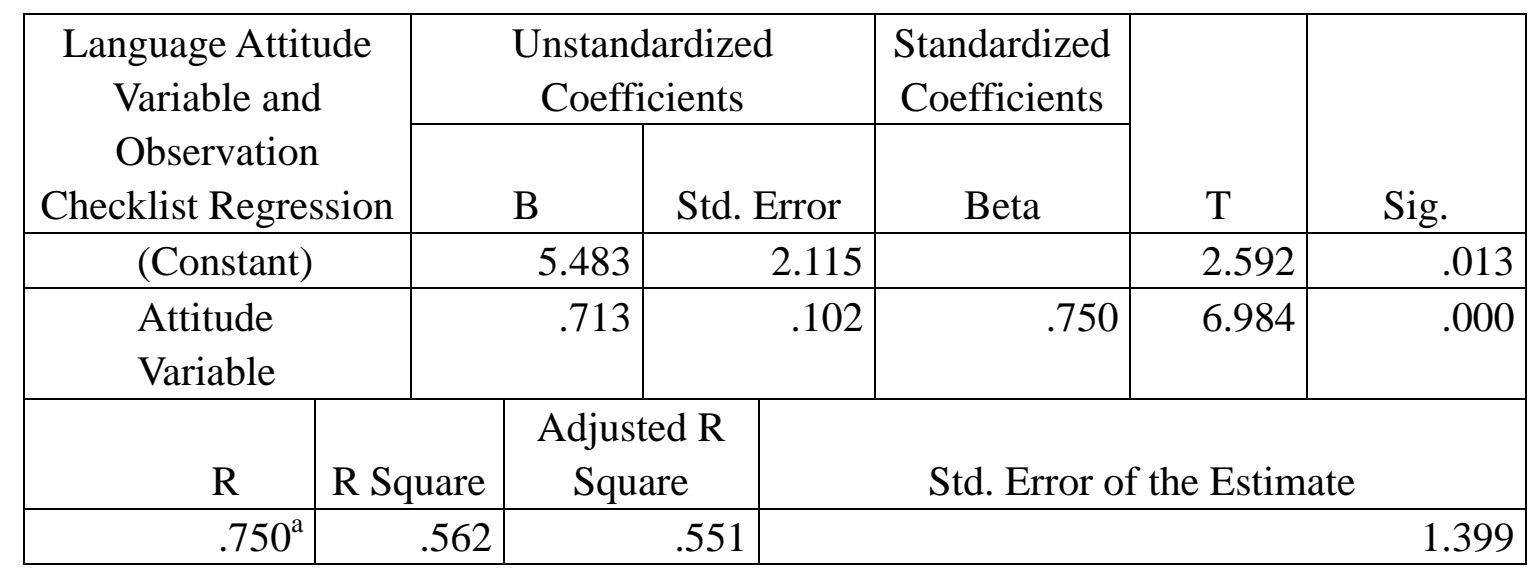

a. Predictors: (Constant), Attitude Variable

b. Dependent Variable: Observation Checklist statements

In table (6), the regression coefficient demonstrates the prediction equations. The R2of (0.562) demonstrates that about $(56.2 \%)$ of the variation in the dependent variables goes back to the independent variable of the study. The results of the regression analysis revealed that the attitude variable predicts the students' English language acquisition with a beta weight of (.750) which is a positive value. These coefficients estimate the strength of the effect of the independent variable (Language attitude) on the dependent variable (English language acquisition) and the strong relation between them. All this answers the second study question, verifies, and accepts its third hypothesis $(\mathrm{p}=.000)$ which is: There is a statistically significant positive relationship between language attitude and English language acquisition in the application of the questionnaire and observation checklist statements on the experimental group or focus group.

\section{To Answer Question Three and Test the Fourth Hypothesis}

The answer to this question could be demonstrated through indicating the correlation between the self-confidence affective variable statements and those of the English Language Proficiency Observation Checklist (ELPOC) as indicated in Table (7):

Table (7): Correlations between Self-Confidence Variable Statements and ELPOC 


\begin{tabular}{|c|c|c|c|}
\hline \multicolumn{2}{|c|}{$\begin{array}{c}\text { Self-Confidence and Observation Checklist } \\
\text { Correlations }\end{array}$} & $\begin{array}{c}\text { Self -Confidence } \\
\text { Variable } \\
\end{array}$ & $\begin{array}{c}\text { Observation Checklist } \\
\text { statements }\end{array}$ \\
\hline \multirow{3}{*}{$\begin{array}{l}\text { Self } \\
\text { Variable }\end{array}$} & Pearson Correlation & 1 & $.758^{* *}$ \\
\hline & Sig. (2-tailed) & & .000 \\
\hline & $\mathrm{N}$ & 40 & 40 \\
\hline \multirow{3}{*}{$\begin{array}{l}\text { Observation Checklist } \\
\text { statements }\end{array}$} & Pearson Correlation & $.758^{* *}$ & 1 \\
\hline & Sig. (2-tailed) & .000 & \\
\hline & $\mathrm{N}$ & 40 & 40 \\
\hline
\end{tabular}

**. Correlation is significant at the 0.01 level (2-tailed).

Table (7) indicates that there is a positive strong relation between self-confidence affective variable statements as indicated in the AFQ and those of the ELPOC as R (40) $=0758$ and the relation is statistically significant as $\mathrm{p}=.000$ (less than 0.01 ). This means that the more language self-confidence the students have the better English language proficiency they get. This could be clear as well in determining the simple liner regression between those two variables as indicated in table (8).

Table(8): Simple Regression Coefficients for the Self-Confidence Variable Statements as Predictor of Observation Checklist statements

\begin{tabular}{|c|c|c|c|c|c|c|}
\hline \multirow{2}{*}{$\begin{array}{l}\text { Self-Confidence } \\
\text { Observation } \\
\text { Regression }\end{array}$} & \multirow[t]{2}{*}{$\begin{array}{r}\text { Variable and } \\
\text { Checklist }\end{array}$} & \multicolumn{2}{|c|}{$\begin{array}{c}\text { Unstandardized } \\
\text { Coefficients }\end{array}$} & \multirow{2}{*}{$\begin{array}{c}\text { Standardized } \\
\text { Coefficients } \\
\text { Beta } \\
\end{array}$} & \multirow[b]{2}{*}{$\mathrm{T}$} & \multirow[b]{2}{*}{ Sig. } \\
\hline & & $\mathrm{B}$ & Std. Error & & & \\
\hline (Constant) & & 5.430 & 2.073 & & 2.620 & .013 \\
\hline $\begin{array}{l}\text { Self } \\
\text { Variable }\end{array}$ & -Confidence & .714 & .100 & .758 & 7.154 & .000 \\
\hline $\mathrm{R}$ & R Square & $\begin{array}{c}\text { Adjusted R } \\
\text { Square }\end{array}$ & \multicolumn{4}{|c|}{ Std. Error of the Estimate } \\
\hline $.758^{\mathrm{a}}$ & .574 & .563 & & & & 1.380 \\
\hline
\end{tabular}

a. Predictors: (Constant), Self -Confidence Variable

b. Dependent Variable: Observation Checklist statements

The simple liner regression between the two variables as indicated in table (8) gives more illustration for the positive strong relation between the self-confidence affective variable and the English language acquisition one as represented in the statements of the ELPOC. The R2of (0.574) demonstrates that about $(57.4 \%)$ of the variation in the dependent variables occurs because of the independent variable of the study. The findings of the regression analysis proved that the self-confidence variable predicts the students' English language acquisition with a beta weight of $(0.758)$ which is a high positive value. These coefficients 
determines the strength of the effect of the independent variable (Language self-confidence) on the dependent variable (English language acquisition) and the strong relation between them. All this answers the third study question, verifies, and accepts its fourth hypothesis $(\mathrm{p}=.000)$ which is: There is a statistically significant positive relationship between the learners' self-confidence and English language acquisition in the application of the questionnaire and observation checklist statements on the experimental group students.

\section{To Answer the Fourth Question and Test the Fifth Hypothesis}

This has been demonstrated through clarifying the correlation between the willingness to communicate affective variable statements as indicated in the affective variable questionnaire (AVQ) and those of the English Language Proficiency Observation Checklist (ELPOC) as indicated in table (9):

Table (9): Correlations between Willingness to Communicate Variable Statements and ELPOC:

\begin{tabular}{|l|l|r|r|}
\hline \multicolumn{1}{|c|}{$\begin{array}{c}\text { Willingness to Communicate Variable and } \\
\text { Observation Checklist Correlations }\end{array}$} & $\begin{array}{c}\text { Willingness to } \\
\text { Communicate Variable }\end{array}$ & $\begin{array}{c}\text { Observation } \\
\text { Checklist statements }\end{array}$ \\
\hline $\begin{array}{l}\text { Willingness to } \\
\text { Communicate Variable }\end{array}$ & $\begin{array}{l}\text { Pearson } \\
\text { Correlation }\end{array}$ & 1 & $.802^{* *}$ \\
\cline { 2 - 4 } & Sig. (2-tailed) & 40 & .000 \\
\cline { 2 - 5 } & $\mathrm{N}$ & $.802^{* *}$ & 40 \\
\hline $\begin{array}{l}\text { Observation Checklist } \\
\text { statements }\end{array}$ & $\begin{array}{l}\text { Pearson } \\
\text { Correlation }\end{array}$ & .000 & 40 \\
\cline { 2 - 5 } & Sig. (2-tailed) & 40 & \\
\cline { 2 - 5 } & $\mathrm{N}$ & & \\
\hline
\end{tabular}

**. Correlation is significant at the 0.01 level (2-tailed).

As it is clear in table (9) that the correlation between willingness to communicate variable statements and the English language acquisition variable which is represented in the statements of ELPOC is highly positive as $\mathrm{R}(40)=\left(.802^{* * *}\right)$. Moreover, this correlational relationship is statistically significant as $\mathrm{p}=(.000)$ which is less than $(0.01)(\mathrm{p}<0.01)$. In other terms, the more language willingness to communicate the English language the learners have, the better English language proficiency they get. This could be demonstrated in the simple liner regression relationship between the language Willingness to Communicate Variable statements and those of the ELPOC as indicated in table (10).

Table (10): Simple Regression Coefficients for the Willingness to Communicate Variable Statements as Predictor of Observation Checklist statement 


\begin{tabular}{|c|c|c|c|c|c|c|}
\hline \multirow{2}{*}{\multicolumn{2}{|c|}{$\begin{array}{l}\text { Willingness to Communicate } \\
\text { Variable and Observation } \\
\text { Checklist Regression } \\
\end{array}$}} & \multicolumn{2}{|c|}{$\begin{array}{c}\text { Unstandardized } \\
\text { Coefficients }\end{array}$} & \multirow{2}{*}{$\begin{array}{c}\text { Standardized } \\
\text { Coefficients } \\
\text { Beta } \\
\end{array}$} & \multirow[b]{2}{*}{ 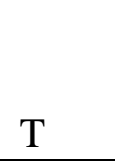 } & \multirow[b]{2}{*}{ Sig. } \\
\hline & & $\mathrm{B}$ & Std. Error & & & \\
\hline \multicolumn{2}{|l|}{$($ Constant $)$} & 4.800 & 1.870 & & 2.567 & .014 \\
\hline \multicolumn{2}{|c|}{$\begin{array}{l}\text { Willingness to } \\
\text { Communicate Variable }\end{array}$} & .750 & .091 & .802 & 8.269 & .000 \\
\hline $\mathrm{R}$ & R Square & $\begin{array}{l}\text { Adjusted R } \\
\text { Square }\end{array}$ & \multicolumn{4}{|c|}{ Std. Error of the Estimate } \\
\hline $.802^{\mathrm{a}}$ & .643 & .633 & & & & 1.263 \\
\hline
\end{tabular}

a. Predictors: (Constant), Willingness to Communicate Variable

b. Dependent Variable: Observation Checklist statements

Table (10) gives more clarification for the positive relation between the two variables of willingness to communicate and the English language acquisition one as represented in the statements of the ELPOC through the simple liner regression between them. The R2of (0.643) indicates that about (64.3\%) of the variation in the dependent variables occurs because of the independent variable of the study. The findings of this regression analysis proved that the willingness to communicate variable predicts the students' English language acquisition with a beta weight of (0.802) which is a high positive value. These coefficients determines the strength of the effect of the independent variable (Willingness to communicate) on the dependent variable (English language acquisition) and the strong relation between them. Thus, the fourth study question and the fifth hypothesis are answered and accepted respectively as $(\mathrm{p}=.000)$ : There is a statistically significant positive relationship between the learners' willingness to communicate and English language acquisition in the application of the questionnaire and observation checklist statements on the experimental group students.

\section{To Answer the Main Study Question and Test the First Hypothesis}

Identifying the positive relationship between the affective variables (motivation, attitude, self-confidence and willingness to communicate) as represented in the statements of AVQ and the English language acquisition and proficiency as represented in the statements of ELPOC answers the main study question and accepts its hypothesis: There is a statistically significant positive relationship between the affective variables and English language acquisition in the application of questionnaire and observation checklist statements on the experimental group students.

\section{Discussion}

The results obtained from the data mentioned in the preceding section indicates a range of potentially significant findings. These findings demonstrated the correlational relationship among the affective variables of (language motivation, language attitude, language self-confidence and the language learners' willingness to communicate).The highest correlation (0.981) was found between the two affective variables of language motivation and attitude. Furthermore, they highlighted the relationship between each of these affective 
variables and the learners' English language acquisition and how they differ in their impact on the English language proficiency of the learners from one affective variable to another. Moreover, for more evidence on those findings, some the results of the related research will be mentioned in this section to sustain those findings.

As for the relationship among affective variables and each other, correlational statistical analysis found that all these variables are interrelated with each other and they have effect on the learners' English language proficiency and acquisition. This effect is positive and it is different from one affective variable to another. For the variable of the language motivation, it affects $(48.7 \%)$ on the participants' English language acquisition as a foreign language. This is consistent with some previous studies (e.g. Dehbozorgi, 2012; Ebrahimi and Heidarypur, 2016; Nafi, et al., 2016; Zaman, 2015; Törnqvist, 2008). This gives an answer for the first question and verification and acceptance for the first hypothesis as mentioned beforehand.

In addition, the variable of language attitude affects (56.2\%) of the English language learning and its acquisition as a foreign or second language, and this also goes in the same direction with some previous studies such as (e.g. Alkaabi, 2016; Moskovsky \& Alrabai, 2009; Muñoz\& Martín 2015; Ranjabar \& Narafshan, 2016). Furthermore, the variable of language self-confidence affects $(57.4 \% \%)$ of the English language learners' proficiency and acquisition, and this is also consistent with the results of previous research (e.g. Basco \& Ho Han, 2016; Khaleghi, 2016). Additionally, the variable of the English language learners' willingness to communicate affects $(64.3 \%$ \%) of English language learners' proficiency and acquisition, and this is supported by the results of related studies (e.g.Farouk, 2016; knell and Chi, 2012).

Another truly remarkable result as it is obvious from these results the differences in the ratios of the affective variables affect the proficiency of the acquirers of the English language, whereas the variable of the English language learners' willingness to communicate had the highest effect $(64.3 \% \%)$. In another words, with regard to the importance of the role that English language learners' willingness to communicate plays-relative to the other three variables - in L2 acquisition, it seems undeniable that it is a major factor in the learning of foreign/second languages, perhaps the most determining one according to the results of the current study. However, other studies (e.g. Alrabai \& Moskovsky, 2016) proved that motivation had the highest effect among the other affective variables on the learners' English language acquisition. All these results as mentioned beforehand answered the current study questions and gave acceptance and verification for this research hypotheses.

\section{Conclusions}

As it was clear from the beginning of the current study, its main aim was to investigate the relation and impact of the four affective variables: motivation, attitudes, self-confidence and willingness to communicate, have - together and separately - on learners' English language acquisition. The study findings stressed that, individually, each of the four variables affects L2 (EFL/ESL) learning and its outcomes, but their "share" is not equal. Among them English language learners' willingness to communicate emerged as by far the most important one. Based on the study results, there are recommendations and suggestions. 


\section{Mll Macrothink}

Journal for the Study of English Linguistics

ISSN 2329-7034

2020, Vol. 8, No. 1

It is recommended for the L2 (EFL/ESL) instructors in the L2 classrooms to enhance the L2 (EFL /ESL) learners' self-confidence and willingness to communicate in English and promote their positive attitudes and motivation for learning the English language. Moreover, L2 (EFL/ESL) instructors have to give much attention to the robust link $\left(.802^{* *}\right)$ revealed between willingness to communicate and L2 (EFL/ESL) acquisition as indicated in this study findings. Furthermore, strong correlations $\left(.981^{* *}\right)$ were also found between the participants' motivation and their attitudes towards learning English. All these considerations and recommendations should be considered by the L2 (EFL/ESL) instructors when dealing with the issue of the affective factors that affect the L2 learners' English language acquisition process.

Dr. Khaled Elshahawy is an Assistant Professor of Applied Linguistics-ELT at the English Language Center at the University of Albaha in Saudi Arabia. He is currently teaching English language courses in Applied Linguistics-English language skills. His main areas of interest include sociolinguistics, communicative language teaching (CLT), computer assisted language learning (CALL) and second language acquisition (SLA).

\section{References}

Alkaabi, A. M. (2016). Saudi Students'Motivation and Attitudes toward Learning English as a Second Language and Their Willingness to Invest in Learning It .M.A. Dissertation, Saint Cloud State University, U.S.A.

Alrabai, F. (2014). Motivational practices in English as a foreign language classes in Saudi Arabia: Teachers beliefs and learners perceptions. Arab World English Journal, 5(1), 224-246. https://www.awej.org.

Alrabai, F. \& Moskovsky, C. (2016). The Relationship between Learners' Affective Variables and Second Language Achievement. Arab World English Journal (AWEJ) Volume.7 Number.2 June 2016 .Pp.77-103. https://www.researchgate.net > publication > 318393638_The_Relationship_

Altmisdort, G. (2016). Assessment of language learners' strategies: Do they prefer learning or acquisition strategies? Educational Research and Reviews. Vol.11 (13), pp.1202-1216.July 2016. https://www.semanticscholar.org . https://doi.org/10.5897/err2016.2755

Arnold, J. (2009). Affect in L2 Learning and Teaching. Estudios de lingüística inglesa aplicada, 9, 145-151. https://www.researchgate.net > publication > 41763148.

Basco, L, M. \& Ho Han, S. (2016). Self-esteem, Motivation, and Anxiety of Korean University Students. Journal of Language Teaching and Research, Vol. 7, No. 6, pp. 1069-1078, November 2016. http://dx.doi.org/10.17507/j1tr.0706.02 
Chen, L. (2009). The Effect of Empathy on College English Speaking. Journal of Asian Social Science.Vol.4, No.8. https://www.semanticscholar.org. https://doi.org/10.5539/ass.v4n8p142

Collier, C. (2016). Classroom Language Interaction Checklist. Cross Cultural Developmental Education Services. www.k12.wa.us/MigrantBilingual/pubdocs/CLIC2016.pdf

Dehbozorgi, E. (2012). Effects of Attitude towards Language Learning and Risk-Taking on EFL Student's Proficiency. International Journal of English Linguistics Vol. 2, No. 2. Www.ccsenet.org. https://doi.org/10.5539/ijel.v2n2p41.

Donovan, L. A., MacIntyre, P. D., (2004). Age and Sex Differences in Willingness to Communicate, Communication Apprehension, and Self-perceived Competence.

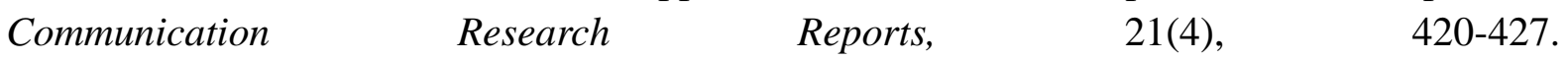
https://doi.org/10.1080/08824090409360006

Dornyei, Z., \& Otto, I. (1998). Motivation in Action: A Process Model of 12 Motivation. Working Papers in Applied Linguistics, 43-69.eprints.nottingham.ac.uk.

D“ornyei, Z., \& Ushioda, E. (Eds.). (2009). Motivation, Language Identity and the L2 Self. Bristol, England: Multilingual Matters.

Ebrahimi, M. \& Heidarypur, M. (2016). The Relationship between Iranian EFL Advanced Learners' Personality Types, Motivation and Language Learning Success. The Journal of Applied Linguistics Vol.9, No.18, pp.143-157. https://pdfs.semanticscholar.org > .

Elshahawy, K. E. (2017). The Impact of Project-Based Digital Storytelling on Enhancing EFL Oracy Skills and Motivation of Saudi University Students. Unpublished $\mathrm{PhD}$ Dissertation. Faculty of Education, Mansoura University, Egypt.

Farouck, I. (2016). A Project-Based Language Learning Model for Improving the Willingness to Communicate of EFL Students. Proceedings of IMCIC - ICSIT 2016.Center of Language Studies. Otaru University of Commerce. Otaru, Hokkaido, Japan.

Gardner, R. C. (2001). Integrative Motivation and Second Language Acquisition. In Z. Dornyei \& R. Schemidt (Eds), Motivation and Second Language Acquisition, (pp. 1-20). Homolulu: University of Hawaii Press.

Gardner, R. C. (2010). Motivation and Second Language Acquisition: The Socio-Educational Model. New York: Peter Lang.

Gass, S., \& Selinker, L. (2008). Second Language Acquisition (3 ${ }^{\text {rd }}$ ed.). Rowley, M: Newsbury House.

Ibrahim, M. K. \& Ibrahim, Y. A. (2017). Communicative English Language Teaching in Egypt: Classroom Practice and Challenges. Issues in Educational Research, 27(2), 2017285. www.iier.org.au.

Khaleghi, A. (2016). Identification of Affective Factors Influencing Students' Low Participation in University EFL Oral Classes: An Iranian Case Study. International Journal of 
Humanities and Social Science Vol. 6, No. 7.www.ijhssnet.com

Knell, E. \& Chi, Y. (2012). The Roles of Motivation, Affective Attitudes, and Willingness to Communicate Among Chinese Students in Early English Immersion Programs. International Education, Vol. 41, Issue 2. https://pdfs.semanticscholar.org >

MacIntyre, P. D. (1994). Variables Underlying Willingness to Communicate: A Causal Analysis. Communication Research Reports, 11, 135-142. https://doi.org/10.1080/08824099409359951

Marcos-Llinas, M. (2007). Variables afectivas en la clase de lenguas extranjeras. Interlingüística, 17, 676-678. https://dialnet.unirioja.es > descarga > articulo

Moskovsky, C. \& Alrabai, F. (2009). Intrinsic Motivation in Saudi Learners of English as a Foreign Language. The Open Applied Linguistics Journal, 2009, 2, 1-10. https://ncys.ksu.edu.sa

Muñoz, A. \& Martín, J. L. O. (2015). Affective Variables in Second Language Acquisition and Their Effect on the Spanish Academic Context. Universidad de Granada. Facultad de Ciencias de la Educación. (Spain). https://ojsspdc.ulpgc.es/ojs/index.php/LFE/index.

Muñoz, C. (2014). Starting age and other influential factors: Insights from learner interviews. SSLLT 4 (3). 2014. 465-484. https://doi.org/10.14746/ssllt.2014.4.3.5. http://www.ssllt.amu.edu.pl.

Nafi,J.S., et al. (2016). Attitudes of Palestinian Undergraduate Students towards Native and Non-Native English Language Teachers and Their Relation to Students' Listening Ability. Journal of Education and Practice .Vol.7, No.26. https://pdfs.semanticscholar.org >

Ortega, L. (2009). Understanding second language acquisition. Hodder Education. London.

Ranjbar, N. A., \& Narafshan, M. H. (2016). Affective Domain: The Relationship between Teachers' Affective Factors and EFL Students' Motivation. Journal for the Study of English Linguistics ISSN 2329-7034 2016, Vol. 4, No. 2. www.macrothink.org

Rasch, S. L. (2016). Students' Perception of Grammar Instruction .A study of the relation between students' perception of grammar instruction and their multiple intelligences. Master's Thesis in English Education. University of Norway.

Sadiq,J. M. (2017). Anxiety in English Language Learning: A Case Study of English Language Learners in Saudi Arabia. English Language Teaching; Vol. 10, No. 7. http://doi.org/10.5539/elt.v10n7p1

Samimy, K., K. \& Tabuse, M. (1992). Affective Variables and a Less Commonly Taught Language: A Study in Beginning Japanese Classes. Language Learning, 42.3:377-398. https://doi.org/10.1111/j.1467-1770.1992.tb01341.x

Saville-Troike, M. (2012). Introducing Second Language Acquisition. Second Edition. Cambridge University Press. United Kingdom. 


\section{Macrothink Institute ${ }^{T M}$}

Zaman, J. (2015). Role of Motivation in Second Language Learning: A study of Private University Students in Bangladesh. Masters in TESOL Dissertation. BRAC Institute of Languages (BIL). BRAC University Mohakhali, Dhaka.

Zhang. W, Su. D, \& Liu. M. (2013). Personality Traits, Motivation and Foreign Language Attainment. Journal of Language Teaching and Research, 4(1). 58-66. https://pdfs.semanticscholar.org. https://doi.org/10.4304/jltr.4.1.58-66.

Zheng, Y. (2008). Anxiety and Second/Foreign Language Learning Revisited. Canadian Journal for New Scholars in Education, 1(1), 1-12. https://files.eric.ed.gov

Zhu, B. \& Zhou, Y. (2012). A Study on Students' Affective Factors in Junior High School English Teaching. English Language Teaching Vol. 5, No. 7. http://dx.doi.org/10.5539/elt.v5n7p33

\section{Appendix 1}

\section{Affective Variables Questionnaire (AVQ)}

Name.

Department:

Major:.

Academic level:

Please specify which of the following categories apply best for each statement in the following questionnaire by ticking $(\sqrt{ })$ in the appropriate column.

$4=$ Strongly agree

$3=$ Agree

$2=$ Disagree

$1=$ Strongly disagree

\begin{tabular}{|c|c|c|c|c|c|}
\hline No. & Statement & 1 & 2 & 3 & 4 \\
\hline 1 & I am enjoying learning English. & & & & \\
\hline 2 & I am motivated to study English even if it were not my major. & & & & \\
\hline 3 & $\begin{array}{l}\text { My goal of learning English is to be competent in it, which is far more than } \\
\text { just passing my exams. }\end{array}$ & & & & \\
\hline 4 & $\begin{array}{l}\text { Studying English teaches me things that are useful to me in my future and } \\
\text { daily life activities. }\end{array}$ & & & & \\
\hline 5 & Learning English will guarantee a good job for me in the future. & & & & \\
\hline 6 & I would not study English if I did not have to. & & & & \\
\hline 7 & During my free time, I prefer to watch an English movie & & & & \\
\hline 8 & $\begin{array}{l}\text { Learning English is necessary for me to understand native speakers and their } \\
\text { way of living. }\end{array}$ & & & & \\
\hline 9 & For me, English native speakers are friendly, polite and thoughtful people. & & & & \\
\hline 10 & For my opinion, it is better to get native speakers of English instructors in & & & & \\
\hline
\end{tabular}




\section{Macrothink}

Journal for the Study of English Linguistics

ISSN 2329-7034

2020, Vol. 8, No. 1

\begin{tabular}{|c|c|}
\hline & addition to non-natives ones to teach at our University. \\
\hline 11 & $\begin{array}{l}\text { I like my English courses because they are easy and useful for my macro and } \\
\text { academic skills. }\end{array}$ \\
\hline 12 & $\begin{array}{l}\text { I think native speakers of English are usually unkind and impolite, so I hate } \\
\text { English and learn it only for getting a good job. }\end{array}$ \\
\hline 13 & $\begin{array}{l}\text { I am keen on expressing my own ideas and participating in the discussions in } \\
\text { my English lectures. }\end{array}$ \\
\hline 14 & I always participate in the activities that occur in English in my Department. \\
\hline 15 & I have my own clear goals to learn English every semester. \\
\hline 16 & $\begin{array}{l}\text { I have a feeling of self- confidence in my language competences when I speak } \\
\text { in English with my instructors and peers. }\end{array}$ \\
\hline 17 & $\begin{array}{l}\text { I never feel self-confidence when I speak in English with my instructors and } \\
\text { peers. }\end{array}$ \\
\hline 18 & $\begin{array}{l}\text { I start to panic if I have to speak in English without preparation during my } \\
\text { lectures. }\end{array}$ \\
\hline 19 & $\begin{array}{l}\text { I get embarrassed to be a volunteer and participate in English with my peers in } \\
\text { my lectures. }\end{array}$ \\
\hline 20 & I always fear that my student peers will laugh at me when I speak in English. \\
\hline 21 & $\begin{array}{l}\text { I can feel my heart pounding when communicating in English because I am } \\
\text { afraid of doing errors and mistakes. }\end{array}$ \\
\hline 22 & I am always willing to communicate with peers and instructors in English \\
\hline 23 & I never feel tense and nervous in communicating in English with the others. \\
\hline 24 & $\begin{array}{l}\text { I like being an actor in an English play or novel to have a chance to } \\
\text { communicate with the others. }\end{array}$ \\
\hline
\end{tabular}

\section{Appendix 2}

English Language Proficiency Observation Checklist (ELPOC)

Student Name:

Undergraduate Level:.

Observation date:.

1= Below standards 2= Approaching standards $3=$ Meeting standards $4=$ Above standards

\begin{tabular}{|c|c|c|c|c|c|}
\hline No. & & 1 & 2 & 3 & 4 \\
\hline 1 & $\begin{array}{l}\text { The student can respond appropriately to common social exchanges with } \\
\text { peers and lecturers such as greetings, giving directions, asking for information, } \\
\text { inquires......etc. }\end{array}$ & & & & \\
\hline 2 & $\begin{array}{l}\text { The student can generate simple or compound sentences in communication, } \\
\text { either in general conversation or as an answer to a question. }\end{array}$ & & & & \\
\hline 3 & $\begin{array}{l}\text { The communicative ability of the student is understood although there are } \\
\text { some pronunciation and basic grammatical errors in his/her communication. }\end{array}$ & & & & \\
\hline 4 & $\begin{array}{l}\text { The student has the ability to begin a conversation or set of questions and } \\
\text { answers about a certain topic in the class. }\end{array}$ & & & & \\
\hline 5 & The student can maintain two-way conversation with another student or adult. & & & & \\
\hline 6 & The student speaks fluently with confidence and imaginative communication. & & & & \\
\hline
\end{tabular}




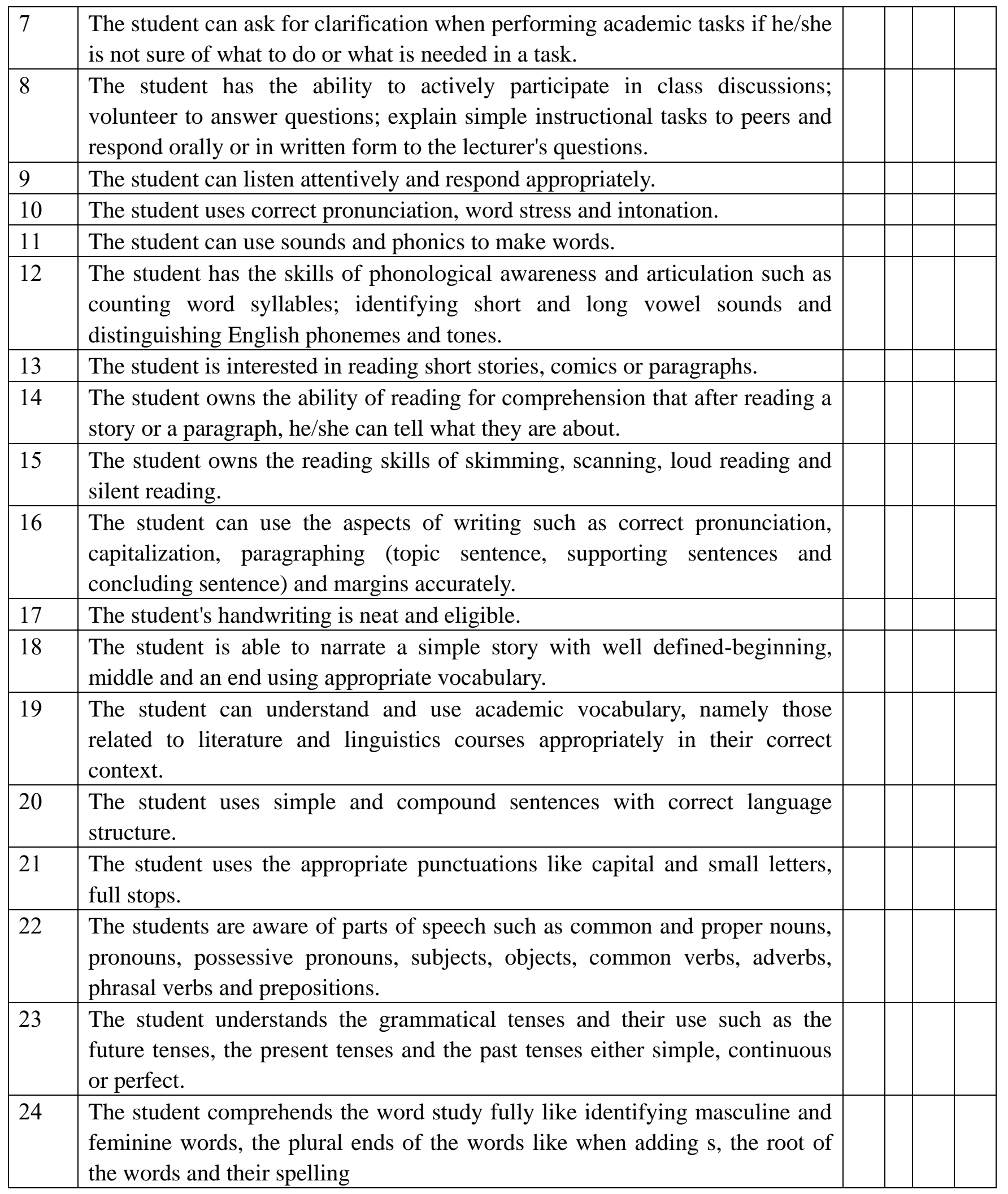




\section{Copyright Disclaimer}

Copyright for this article is retained by the author(s), with first publication rights granted to the journal.

This is an open-access article distributed under the terms and conditions of the Creative Commons Attribution license (http://creativecommons.org/licenses/by/3.0/). 